\title{
Alternative use of farmlands as tourism and leisure resources: Diversification, Innovations and Competitiveness
}

\author{
A. Oriade ${ }^{\mathrm{a}} *$ R. Broad ${ }^{\mathrm{a}}$ and S. Gelder ${ }^{\mathrm{a}}$ \\ ${ }^{a}$ Department of Marketing, Innovation, Leisure \& Enterprise, University of Wolverhampton, UK.
}

Dr Ade Oriade

Department of Marketing, Innovation, Leisure \& Enterprise

University of Wolverhampton

United Kingdom.

ade.oriade@wlv.ac.uk

Dr Roy Broad

Department of Marketing, Innovation, Leisure \& Enterprise

University of Wolverhampton

United Kingdom.

$\underline{\text { R.Broad@wlv.ac.uk }}$

Steve Gelder

Department of Marketing, Innovation, Leisure \& Enterprise

University of Wolverhampton

United Kingdom.

S.Gelder@wlv.ac.uk 


\title{
Alternative use of farmlands as tourism and leisure resources: Diversification, innovations and competitiveness
}

\begin{abstract}
Even though farm-based tourism has been around for some time, the contemporary development in farm business in the United Kingdom is intriguing and histrionic. Based on the contemporary situation, this study explores issues relating to diversification, innovation and competitiveness in farm attraction context. The study employed case study strategy and adopted qualitative research approach by conducting interviews in three farm attractions in Shropshire, West Midlands, United Kingdom; utilising a template approach to data analysis by identifying key themes a priori. Findings support the conception that different farm organisations have different needs that require different level of innovativeness. Three element of innovation distinctively emerged namely: organisational, product and marketing innovations. Based on the findings practical implications were identified.
\end{abstract}

Key words: farm attraction; rural tourism; visitors experience; leisure; diversification; innovations; resource use; competitiveness; farm shop; destinations

\section{Introduction}

Liu (2010) noted that chief among the aims of rural development is to spark a new role for rural areas by turning rural landscapes into leisure and recreational paradises for the stressedout urban population. Farms have been playing this role, and not only that the number of farm tourism organisations has been growing, there have been growth in the number of trade associations and organising bodies too. Examples include National Farm Attractions Network (NFAN), National Farmers' Retailers and Markets Association (FARMA), Farm Stay UK and others, representing member farm organisations in sectors spanning accommodation, catering, retail and attraction/visitor activities. While this sector is wide ranging, the focus of this paper is on catering, retail and attraction/visitor activities as oppose to farm accommodation. NFAN (2013) estimated that there are approximately 400 farm and rural attractions in the UK welcoming 20 million visits a year. NFAN indicated that its members, comprising of over 200 farms, collectively invest around $£ 20 \mathrm{~m}$ annually in developing and improving their attractions hence contributing to the local economic and social lives. No 
doubt farm tourism organisations are investing in their businesses to create appealing products and atmospheres in meeting modern day visitors' needs and sociocultural developments of places they are located.

The trends seen in farm business in the United Kingdom (UK) are quite intriguing and histrionic particularly in terms of diversification. On one hand, it is intriguing in the sense that the rate at which farms businesses expand and the magnitude of efforts expended are phenomenal. On the other hand, histrionic because of the level and nature of expansion witnessed is often distinct from the core business. Focus has been shifting to tourism and leisure. Many farmlands these days have been transmuted to tourism and leisure resources. Although this is not a new development; Shapley and Vass (2006) pointed out that this has a long-standing history in Europe and Australia; UK happened to be a late-starter following several socio-economic developments that motivated diversification among British farmers. This view somewhat characterises farmers as market followers as oppose to recent development that support the entrepreneurial and innovative nature of farm diversification (Morris, Henley \& Dowell, 2017). Traditionally, rural destinations are settings that provide alternatives to the tense urban pace of living, where visitors can enjoy tranquillity, nature, authenticity and well-being activities (Li, Rahimi \& Stylos, 2017). Clearly the current sprawl of farm tourism is gradually becoming antithesis to the traditional rural tourism where visitors tend to be explorer, travelling in limited number rather than en masse. While this form of development can deliver opportunities and economic advancement to a region, it can also be challenging to operators and their business processes because they will be dealing with new product, new market and possibly new processes. In other word, they will need to reinvent themselves and innovate - an intensive knowledge-based process of seeing and doing things differently (Jalonen, 2015).

Farms often rely on their land and location resources which determine most of their operations e.g. arable farming, pastoral farming or mixed farming. However, as noted by Shapley and Vass (2006) British farmers following a series of socio-economic developments, such as the episodes of foot-and-mouth disease (FMD), were motivated to diversify. The success of an organisation that diversifies its operations hinges on being able to pursue market-driven, innovative and sustainable strategies (Suess-Reyes \& Fuetsch2016). While land and location resources remain vital element farmers can anchor their diversification strategies upon the resources in focus and must be able to create value for the customer 
(Andersen, 2010). Resource-based view (RBV) propounds that valuable, rare, inimitable and non-substitutable resources are the determining basis for superior organisation performance (Barney, 1991) particularly if the business has the capability of efficiently managing and bundling the resources (Sirmon et al., 2011). The tenet of this view is hinged on two principal assumptions that resources must be heterogeneous and immobile whilst recognising two types of resources: tangible and intangible; the latter being more able to generate a competitive advantage because of their rarity and socially complex characteristics that hinder imitation. Farmlands, as tangible resources, in prime and/or rare location can be valuable resources that can be difficult to replicate. However, ability to develop and market a rare and non-substitutable resource and sustain a business remains vital, equally (Andersen, 2010). Through the structural coupling of the two types of resources, capabilities that are difficult to imitate are generated (Suess-Reyes \& Fuetsch, 2016).

Hjalager, Kwiatkowski \& Ostervig Larsen (2018) however noted that rural tourism enterprises and destinations remain slow movers in terms of innovation endeavours. Many tourism organisations are slow to innovate because preconditions for innovation are lacking (Kessler et al., 2015). Fadden and Gorman (2016) also noted that farm innovation research need to focus on elements of innovations that are necessary to run a farm business in a competitive market environment both at household and organisational levels; this study however focusses mainly on organisational level. To address the extant gaps in the literature and contribute to theory development, this study adopts qualitative research approach by conducting interview in three farm attractions in Shropshire, West Midlands, UK. The study addresses on four research questions:

RQ1. What are the key drivers for diversification in Farm Attractions? RQ2. What are the elements of innovation in Farm Attractions context? RQ3. What are the innovation practices in Farm Attractions context that create value, competitive advantage and differentiation?

RQ4. How do Farm Attraction organisations effectively manage innovations to sustain business continuation, profitability, brand image, stakeholder benefits and visitor satisfaction?

The remainder of the paper is structured as follows. The next section presents the review of literature and development of conceptual framework. The subsequent section discusses the 
methodology with description of the three case farms referred to as Farm 1, Farm 2 and Farm 3. The follow-on sections present the findings and discussion of findings.

\section{Literature and theoretical background}

\section{Development of farm-based tourism}

As noted by Shapley and Vass (2006) farm-based tourism has been around for sometimes. It has a long-standing history in Europe and Australia with UK being a late-starter as an aftermath of several socio-economic developments and farm-related health issues such as foot and mouth disease that motivated diversification among British farmers. Having said this, the demand and offer of recreational activities on farms, worldwide, has grown over time and promises increase in the future because of the benefits accruable to farmers and visitors (Barbieri, Xu, Gil-Arroyo \& Rich, 2016). Research in this topic area has been wide ranging including, but not limited - nature, structure and development (Pizam \& Pokela, 1980; Gasson, 1988; Bowler et al. 1996; Shapley \& Vass, 2006; Forbord, Schermer \& Griebmair, 2012); impacts and effects (Maude \& Van Rest, 1985); gender issue (GarciaRamon, Canoves \& Valdovinos, 1995; Brandth \& Haugen, 2007; Brandth \& Haugen, 2010; Pettersson \& Cassel, 2014; Cassel \& Pettersson, 2015); tourist experience and marketing (Clarke, 1996; Clarke, 1999; Barbieri et al., 2016); country by country analysis (Frater, 1983; Davies \& Gilbert, 1992; Potocnik-Slavic \& Schmitz, 2013); operator and tourist motivation (Ingram, 2002; Ollenburg \& Buckley, 2007); management approach and behaviour (Park, Doh \& Kim 2014; Engeset \& Heggem, 2015) and entrepreneurship (Haugen \& Vik, 2008; Phelan \& Sharpley, 2012). It would be noted that some areas receive more attention than others. Gender and gender related issues are widely researched in the context of farm tourism exemplifying the notion observed by scholars (e.g. Shapley and Vass, 2006) that farm tourism is a supplementary enterprise managed mostly by women. This view is however debunked by Haugen and Vik's (2008) study that did not find support for the evidence that suggest farm-based tourism are mainly operated by women.

Another area of research focus noteworthy is development, incorporating diversification and motivation for starting farm tourism business, because it has been widely addressed.

Development of farm tourism has been conceptualised from two main perspectives - reactive and proactive. The consensus has predominantly leaned towards reactive perspective. This lays credence to the notion that development or starting farm tourism enterprise is necessity induced rather than development inclined. Entry into this type of tourism is often seen as 
mainly necessity driven (e.g. Ilbery \& Bowler, 1998). Ilbery \& Bowler (1998) in their England and Wales study concluded that farmers who are willing to diversify are those who operate large farm with a significant level of indebtedness. However, a stream of literature (e.g. Engeset \& Heggem, 2015) is emerging emphasising market orientation and farm resource-based approach to development to meet up with the current farm tourism market that is characterised by tough market environments, demand for quality products by increasingly demanding tourists and strong competition. Other challenges are related to issues confronting small and family-run businesses such as family members finding it hard to reach a consensus, relying solely on the competence of one family member; impact on family life and host of other related family-run business complexities (Shapley \& Vass, 2006; Morris, Henley \& Dowell, 2017).

\section{Farming and diversification}

Diversification has been a popular topic in tourism for many decades particularly in the context of rural and farm-based tourism. Andersen (2010) noted the differences between resource-based diversification and diversification based on market orientation (market/product-led). Knowles (1996) also differentiated between related and unrelated diversifications. Closely related to market-oriented diversification is the notion of unrelated diversification commonly found in farm diversification context. Unrelated diversification implies business expansion beyond the present industry. It denotes venturing into products and markets that has no clear relationship with the present product and/or market (Knowles, 1996). Ilbery (1991) defined farm diversification, from unrelated diversification perspective, as the channelling of farm resources into new unconventional, non-agricultural enterprises operated on/within an existing the farm. This (re)channelling of resource often requires further resources such as finance, labour and skills; these factors have been found to be the challenges (Sharply \& Vass, 2006; Morris, Henley \& Dowell, 2017) facing farm organisations among others. Despite numerous challenges identified, studies (e.g. Barbieri \& Mahoney, 2009) have found goal pursuit a significant motivator of diversification.

Drivers and opportunities for diversification will vary widely and would be premised on individual circumstance, abilities and incentives (Morris, Henley \& Dowell, 2017). Organisations may make decision to venture into unrelated business because their current business is declining, have ambitious management/board that would like the business to chart new course, or may have identified that there is an area which could be exploited better. This 
is more so in the UK with declining subsidies and falling land prices, and recently uncertainty brought about by Brexit. Farmers' willingness to diversify to venture such as tourism services may be because of a variety of factors, including: economic need for diversification, physical/geographical characteristics of the farm, perceptions of the socio-economic role of farming, demographic and lifestyle factors, availability and nature of public sector support, and perceptions of tourism as diversification option (Nickerson, Black \& McCool, 2001; Sharply \& Vass 2006). Whilst availability of financial support is widely claimed to be an important source of encouragement for diversification (Fleischer \& Felenstein, 2000), Sharply \& Vass' (2006) work indicated that despite the potential cost of diversification government provision of grants is not a pressing facilitating factor. Also, the literature is quite divided on tourism diversification contribution to farm incomes. Authors such as Oppermann (1996) and Hjalager 1996 concluded that tourism contributes relatively little to farm incomes whilst Morris, Henley and Dowell (2017) found contradictory evidence on this matter.

\section{Innovations}

Appreciable amount of studies has been conducted in the area of innovation in tourism both at organisational level (e.g. Camison \& Monfort-Mir, 2012; Yang \& Tan, 2017) and destination level (e.g. Zach, 2011; Schofield et al., 2018; Martinez-Perez, Elche \& GarciaVillaverde, 2019). Johannessen (2013) refers to innovation as the application of new ideas with the aim of creating value. Some of the studies (e.g. Buhalis and Law, 2008; Morris, Henley \& Dowell, 2017) looked at innovation from technology adoption perspective whilst others (e.g. Camison \& Monfort-Mir, 2012; Schofield et al., 2018) examined and discussed innovation holistically. Hjalager, Kwiatkowski \& Ostervig Larsen (2018) noted that Rural tourism enterprises and destinations remain slow movers in terms of innovation endeavours; they identified five innovation gaps in Scandinavian rural tourism namely portfolio gap, policy departmentalization gap, knowledge gap, change motivation gap, and resource interpretation gap. While these gaps are straight forward to grasp and assess, with limited resources how small, family run tourism enterprises can bridge these gaps continue to be a challenge. However, one aspect of the gaps identified that relates to the study mostly is the resource interpretation gap. Conceptualising innovation however remains controversial because studies from diverse fields of research are fragmented (Toivonen \& Tuominen, 2009). Following the traditional Schumpeterian approach OECD (2005) in the Oslo Manual offered four classifications of innovation: product innovation, process innovation, marketing innovation and organisational innovation, the model which is adopted in the current study. 
The model provides a more realistic outlook to understanding innovation as it compartmentalises innovation into distinctive elements that can be assessed and modified at organisation level (Toivonen \& Tuominen, 2009).

Process innovation is the implementation of a new or improved production and/or delivery system, with attendant changes in techniques and/or equipment (Aldebert, Dang \& Longhi, 2011). Process innovations aim at greater efficiency in terms of reduction in costs of production and/or delivery, and enhancement of quality. Trunfio and Campana (2019) term it as backstage activities that enhance efficiency and productivity through technological investment and generate new combinations of processes. Marketing innovation pertains to development and deployment of a new marketing technique resulting in significant changes in the marketing mix. Unlike process innovation, its sole aim is customer satisfaction and development of new markets/product (Aldebert, Dang \& Longhi, 2011). Product innovation which is often the focus of many tourism (and hospitality) organisations denotes changes which tourists can directly observe and consider as novel (Hjalager, 2010). According to Yang and Tan (2017) product innovation in the sector is not necessarily technology-driven even though focus is often on technological and communicational innovation (Hjalager, 2010), it rather involves incorporating new ideas and activities into a product profile to create valued tourist experiences. Product innovation is somewhat easy to achieve as operators can with ease expand their product profile by adding an imaginative component (e.g. introducing bicycle polo or accessory making) to their offering. Lastly organisational innovation refers to the adoption of new or considerably changed strategic orientations, the implementation of advanced management practices, and the introduction of markedly reformed corporate structures (OECD, 2005). However, Toivonen and Tuominen (2009) argued that the distinction between the different types of innovation exhibits blurry boundaries particularly in tourism and hospitality contexts. They however put forward four categories of innovations namely experience co-creation, smart destinations, e-participative governance, and social innovations. This typology is however limited to destination level making it difficult to adopt in organisation level research. Also, the focus is predominantly technological save the fourth category that captures interaction among actors.

\section{Market demand and the competitive environment}

Leisure activities remain a priority for consumers and weather patterns affect demand for food and drink in outdoor settings, with young people showing a desire to strike a balance 
between health and indulgence (Davies, 2019). Farm shops and cafés are seen as part of the leisure destintion sector offering a different casual eating and food retail experience. The interest in sourcing farm fresh local foods for domestic and commercial purposes has increased over the last two decades inline with growing trends in healthy eating, ethical and environmental concerns. Fresh meat sales grew by $1 \%$ in 2018 with poultry still the most popular category, particularly organic, registering $2 \%$ growth with the caveat that future growth in meat sales remains marginal (Euromonitor, 2019). This is offset by the growing interest in vegan diets and sourcing locally produced fresh fruit and vegetables which recorded a $1.4 \%$ increase in sales in 2018 despite the extreme weather patterns in the UK which led to lower yields and higher prices (Euromonitor, 2019).

In a competitive environment, it is important to understand to what extent farm shops and alternative on-farm activities are driven by market demand or are primarily product led by the need sell their own produce. Morris et al (2017) identified farm diversification was conditioned by the wider considerations of farm identity, social and territorial context, and the particular circumstances of the farming household concerned. Family run farms face a number of continuing choices influenced by the need for income generation balanced by onfarm or off-farm pluriactive resources, knowledge and expertise. The motives for farm diversification may change over time but cannot ignore the characteristics and dynamics of the market place. Meert et al (2005) note that direct sales of farm produce are popular choices as the demand for fresh food at 'farm' prices is popular with consumers, require little investment, additional knowledge or extra resources to start a farm shop business. Once 'inbusiness' farm shops are adept at satisfying consumer demand by adding products requested by customers. To be successful in diversifying farming business, farmers need to be sensitive to consumer expectations, to create a positive experience for those who buy produce or services in a farm shop (Brandth and Haugen, 2011). The growth in popularity of farm shops in the UK is reflected in the strength of the 'farm shop' as an identifying brand, which farms can leverage for their own commercial benefit. The ability to create a sense of 'place' and a unique visitor experience for the farm shop and café consumer using local produce as a tourist destination is recognised widely with local food used to differentiate the farm shop concerned (Haven-Tang and Jones, 2005). 


\section{Conceptual framework}

According to OECD (2005) to identify the full range of changes that organisations make to improve performance and enhance their economic success requires a broader framework than technological product and process innovation. The framework presented here (figure 1) is deemed sufficient to aid the examination of farm tourism diversification, innovations and Competitiveness because it takes into consideration the full range of elements of innovations and the competitive environment an organisation resides. In summary figure 1 presents the organising thought of this study, which is undepinned by resource based view theory which propounds that resources are the determining basis for superior organisation performance. The tenet of this view is hinged on two principal assumptions that resources must be heterogeneous and immobile whilst recognising two types of resources: tangible and intangible. Even though intangible resources are usually seen as the main source of sustainable competitive advantage, farmlands, as tangible resources, if in prime or rare location can be a valuable resource that can be difficult to replicate. Lange, Piorr and Zasada (2013) emphasised the importance of location and clustering of businesses in the context of farm tourism equally indicating the importance of tangible resource. Following RBV this study conceptualises resource as consisting of two elements - the tangible and intageble. This is consistent with Haugen and Vik's (2008) view of farm resources as consisting of buildings, land, competences of farm family and other assets. The intangible element is envision in this study as the farm family/organisation's capabilities and knowledge, depicted as the ability of the organisation to reinvent and manage its tangible resources, the farm. Rare resources when appropriately managed can lead to competitiveness and enable an organisation to survive in the business environment (Yang \& Tan, 2017). Drawing from Walsh, Lynch and Harrington (2010), small tourism organisations that strategically practice innovation are able to maximise capacity and profitability, and achieve competitiveness through effective deployment of their resources. 
Fig 1. Conceptual framework
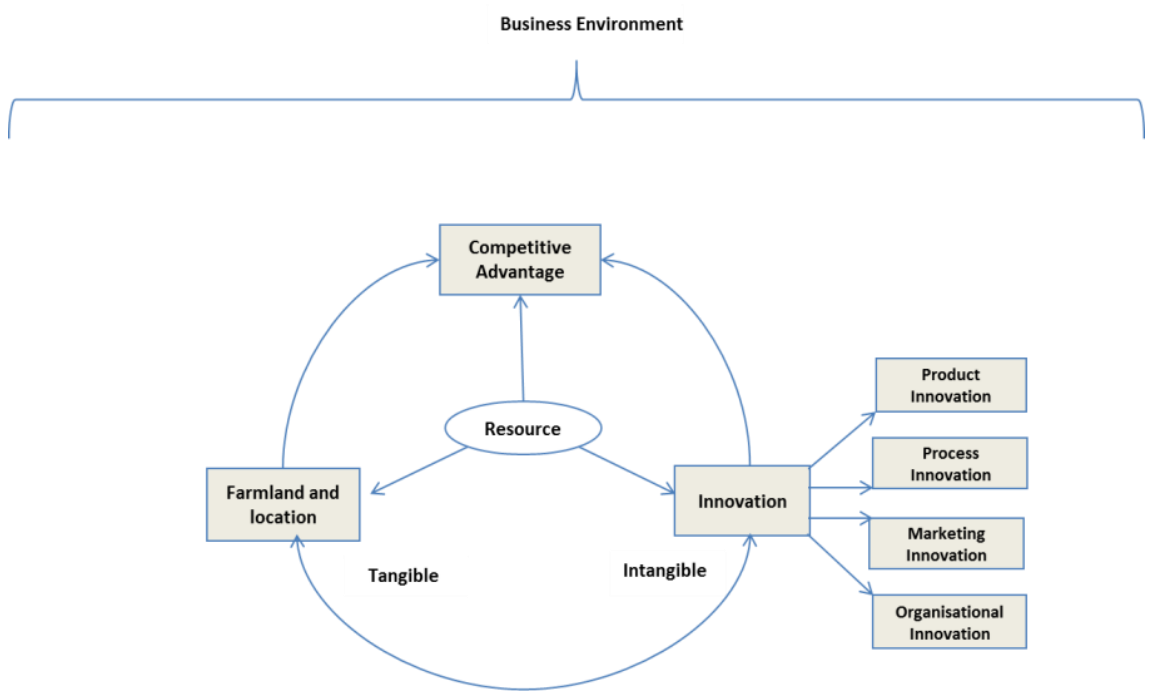

\section{Methodology}

\section{Research area and Cases}

The research was undertaken in Shropshire, a county in the West Midlands of England. This area fits what Ritchie and Lewis (2003) describe as pre-defined quota because of its peculiarity and its recent focus on visitor economy priorities which has witnessed recent Department for Environment, Food and Rural Affairs (defra) $£ 500,000$ allocation to aid rural tourism growth in Shropshire (Shropshire Star, 2015). It is bordered by Wales to the west, Cheshire to the north, Staffordshire to the east, and Worcestershire and Herefordshire to the south. Data were collected from three farm organisations. Each organisation was chosen because its diversified (supporting) operation(s) can be categorised as one or combination of catering, retail and attraction/visitor activities. And, principally, the operation takes place on a farmland. A brief background of the three organisations is provided in the following subsections.

\section{Case organisations}

\section{Case study 1}

A Shropshire beef farm run by the same family since 1919, the café and shop employ 15 staff including 2 chefs and a butcher plus a number of casual staff for events e.g. weddings, concerts and polo matches. The farm shop opened in 2006 in a garage and is now operating from dedicated premises with an adjoining café which opened in 2009. The shop and café 
now cater for various events, weddings, occasions e.g. Burns Night, farm tours, pop-up opera, concerts, wakes, boot camp and the latest innovation Polo. The farm shop and café are very popular and includes online sales, particularly for their Hereford beef. The farm shop, café and associated activities are run as a separate business with annual sales heading towards $£ 1.0 \mathrm{~m}$. There is no organised planning process for the business and marketing is ad-hoc driven by the need to sell tickets for the different events. The family discuss the priorities in the business but do not always agree. For example; the farm buildings are used for events like pop-up opera but this may compromise the farming activities. This is a successful business due to the energy and creativity of the family members running it.

\section{Case study 2}

A family run tenanted farm in Shropshire with 2 staff on the farm and 8 staff in the shop and café, plus approximately 10 part time staff for busy periods. The farm shop and café are adjacent to the A458 to mid-Wales with a good level of passing trade, particularly weekend breakfasts. Development of the farm shop and café is limited by the available space and the willingness of the landowner to have the business expand on the tenanted farm. For example; the family are keen to develop a new tourist business based on glamping pods but this will be on a different site. The father acts as managing director and says that most problems can be resolved amicably around the large table in the farmhouse kitchen.

\section{Case study 3}

A family owned Shropshire estate of 1800 acres with 5 farms (one tenanted) farming beef, lamb and arable. The farm shop and café just off the A49, employ 45 full and part time staff are adjacent to an historic battlefield site which is a local visitor attraction. The family saw this as a once in a lifetime opportunity and it was always intended to develop the farm into a farm shop with a café adjacent to the battlefield site and church but nothing really happened until 2002 when an external consultant looked at the whole estate to decide what the best options were. The requirements of the historic battlefield site were of paramount importance. A new site access road was required and the planning application took approximately 10 years for approval. The farm started by selling out of a freezer at the gate but the vision was always a proper farm shop to take advantage of the available buildings. When everything was settled the family started to implement the plan and develop the business to the success it is today. For example; the farm shop and café have an adjacent battlefield museum and a falconry tourist attraction operated as a concession on the estate. 


\section{Methods}

\section{Data collection}

A qualitative, case study research design was adopted incorporating collection of data via semi-structured interview and observations. Qualitative inquiry process enables focus to be on interpretation and meaning people ascribe to the social world around them hence its adoption helps this study to explore social and human problems in depth (Creswell, 1998). In collecting the primary data, samples were drawn from farm attractions in Shropshire, West Midlands, UK. Five organisations were contacted by letter and a follow-up email requesting their participation. Each invitation included explanation of the purpose of the study and how information supplied will be used. Out of the five organisations contacted, one did not reply and four agreed to participate; however, one of the four was later dropped because its operations do not meet the criteria set in the opening paragraph of this section. Hence interviews were carried out in case organisation 1 (two respondents - a female and a male), case organisation 2 (one male respondent) and case organisation 3 (one male respondent); all in the category of director/owner. Qualitative data are in depth descriptions of circumstances, people, interactions, observed behaviours, events, attitudes, thoughts and beliefs (Patton, 2002) hence qualitative research, and particularly this study, was more about the richness of the data than number of respondents so far the aim of the study is achieved considering necessary epistemological, methodological and practical issues (Baker \& Edwards, 2012). Each interview session, lasting for an average of 45 minutes, was audio recorded and information collected were later transcribed by the second author. To ensure the correctness of the information collected, the audio recordings were played back multiple times to make sure that the communication between researchers and participants was accurately transcribed because valid qualitative research entails credibly presenting social meanings and/or interpretations to the readers (Kuzmanic, 2009).

\section{Data analysis}

Utilising NVivo11, data were analysed based on the template drawn from the framework in figure 1. Template analysis is an approach of analysing qualitative data drawing up a template as an essential list of the codes or categories that represent the themes revealed from the data (King, 1998). Template analysis makes use of combination of deductive and inductive approach to qualitative data analysis; codes are predetermined and can be adjusted in the course of data collection and analysis. In this study, coding started from general to 
detailed (e.g. Coffey \& Atkinson, 1996). The first and second authors did joint coding, reviewed the codes and had discussions about rationale for coding. This, as suggested by Bazeley and Jackson (2013), ensures consistency and reliability.

\section{Results and discussion}

The conceptual framework (figure 1) formed the foundation for the analysis for this work examining the key elements presented therein. The idea that when small tourism organisations strategically practice innovation, their resources can be utilised to maximum capacity and profitability, and competitiveness (Walsh, Lynch \& Harrington, 2010) is pivotal to the analysis. Drawing from resource-based view, and demarcating tangible and nontangible resources, tangible resources, in this case, farms often are subject of diversification necessitating the development and management of intangible resources - organisation's capabilities and knowledge. Initial coding of the data was based on themes generated from the framework namely: competitive advantage, drivers of diversification, elements of innovation, innovation practices and managing innovations. Figure 2 depicts the interconnectedness and commonalities among the themes corroborating Walsh, Lynch \& Harrington's (2010) submission about the central importance of the firm-level innovation in the in ensuring small tourism organisation competitiveness.

\section{Resource base}

Resource being the central theme in this study depicts farm-based resource and location plays a pivotal role. Consistent with previous research (e.g. Bowler et al. 1996), this study is in agreement that location-specific combination of resources influence business/product development. The findings also support the notion that diversification is easier when existing resources can be transferred to another form of business activities (Haugen and Vik, 2008). This could be seen as a facilitating and/or constraining factor. The statement 'If we could find a way round it and get more space, there would be growth of the gift shop' by one of the respondents exemplifies the limiting nature of existing tangible resources which cannot be readily transferred into a business opportunity. Expansion can be curtailed as noted by this respondent who further explained that 'in fact we would like to extend the café but can't at the moment due to restrictions on planning and the car park would not sustain an increase'.

However, farmland and location as tangible resource remains the vital link between the key variables. It was reported that the use of the tangible resource - landed property which ' $k e p t$ its character', in the development of new product/business 'generally works quite well'. Also 
the business vison is 'really guided by the site and the buildings which were in quite good condition'. Overall, the farmland and location determine the type of diversification and extent of business development. This invariably shapes the innovativeness of the organisation in terms of knowledge and skills development.

\section{Knowledge and skills}

The literature makes distinction between farm family Knowledge and skills and farm organisation Knowledge and skills. The focus here is on the organisation although the two cannot be entirely dissociated due to the micro nature of many family business particularly those in farm attraction sector. This aspect is mainly a challenge for the farm organisation as directors often have to be multitaskers who possess all the skills and knowledge required in running the business. While all the directors interviewed possess formal educational qualification and were professionally trained, they were confronted with doing things by themselves and train for basic operations that should be handled by other personnel in the organisation. For example, one of the respondents stated 'I would like to be a manager and not do all these things but I believe you should be able to do everything so 'I even went on a butchery course when we started'. This has an implication for the organisation because they need to be able to empower and equip staff to deal with operational issues when they are not available. Schofield et al (2018) and Toivonen and Tuominen (2009) emphasised the importance of knowledge sharing and collective innovativeness in developing competitiveness. Skills management could hamper innovation in the farm attraction context as the owner/manager may fall into trap of being a 'jack of all trade' rather than a manager. 
Fig 2. Relationships between themes

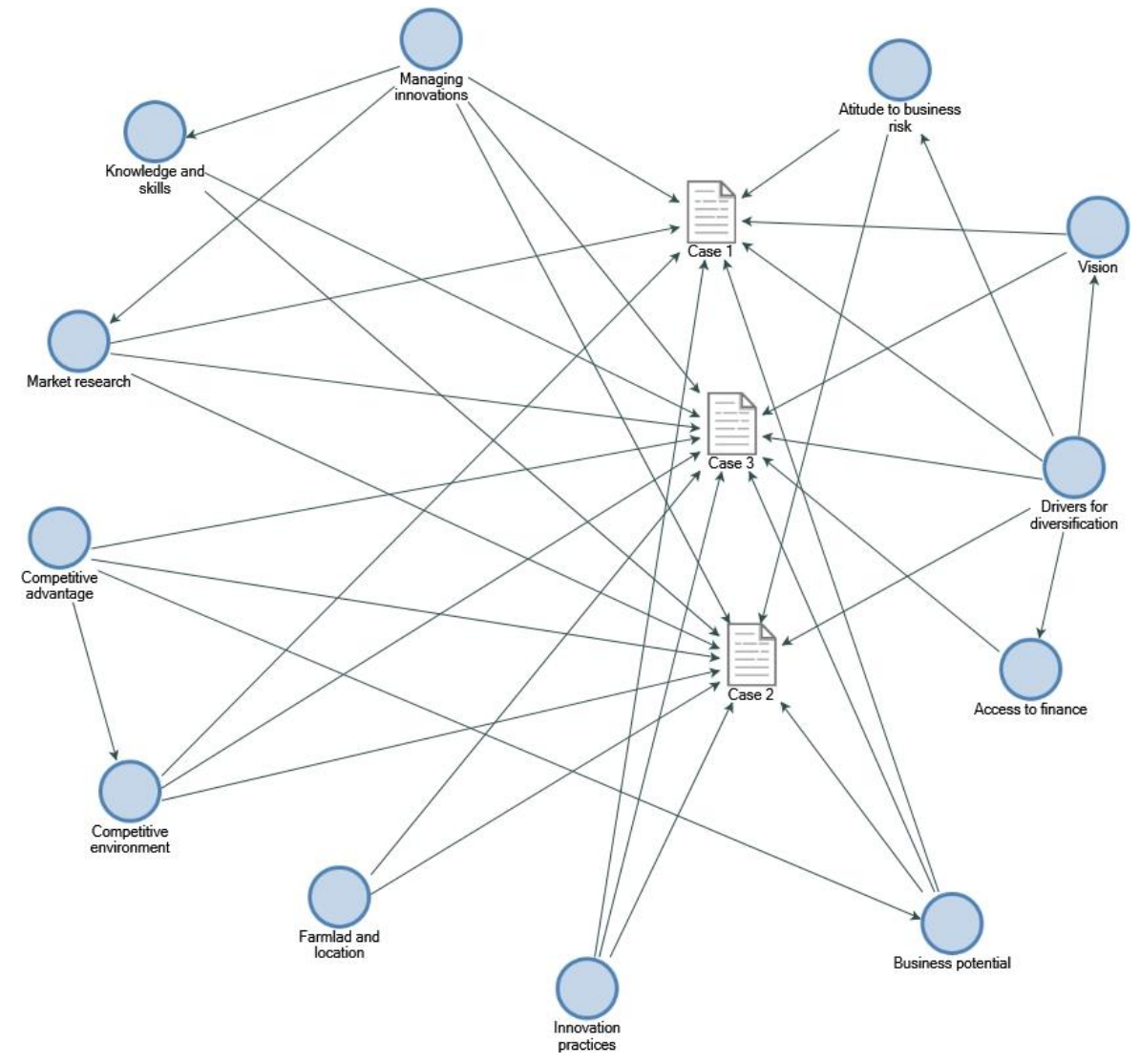

\section{Diversification}

Need for diversification is common to the three case organisations in this study although motivations differ. Previous research (e.g. McFadden \& Gorman, 2016; Haugen and Vik, 2008; Sharply \& Vass 2006) suggested that farm tourism diversification is a survival strategy for farms that are in financial difficulties. It was found that financial survival is one of the key drivers as exemplified by one of the respondent that 'It was a growing realisation that the farm could not survive financially as a beeffarm and is not large enough to be a mixed arable farm'. Another comment 'it was always the idea of running a farm shop as a sales outlet for our beef that was the main motive to bring in extra income.' equally reinforce this finding. It was also found that there were constraints presented by the suitability of the land for farming. The importance of this issue is exemplified in the following quote from one of the respondents:

Our farm of 420 acres (160 hectares) is a mixed farm 200 arable, and 200+ is parkland, this has limitations, we can't plough up the parkland as it's a tenant farm, the farm lies heavy so it's not suited for high value crops, we wondered what we could do, we were prepared to try anything... 
However, it should be noted that farm tourism can also be a purposely developed business as seen in case 3 in this project. This leads to the issue of vision, goal and focus which came out strongly in analysis of this study.

\section{Vision}

The results of this study are congruent to Barbieri \& Mahoney's (2009) submission that goal pursuit is a significant motivator of diversification. There seem to be a clear focus of what the organisations want to achieve. For example 'vision was always a proper farm shop to take advantage of the building we have." And "we had an idea that we wanted to take forward.' For instance, Case 1 took advantage of relocation to rural setting to expand and therefore desires to expand to create wealth for the family; Case 2 aims is to survive; whereas Case 3's vision from the onset is grand: to create a business on a large scale using an historic location to create an attraction. These findings corroborate the work of Morris et al (2017) that concluded that farm diversification is premised on a wide range of considerations including farm identity, social and territorial context, and the particular circumstances of given farming household. The idea that starting farm tourism enterprise is necessity induced rather than development inclined (Ilbery \& Bowler, 1998) is not fully substantiated in this study; it was found that starting a farm-based tourism business can also follow a market orientation supporting Engeset and Heggem (2015) findings.

\section{Attitude to business risk}

Growth can however be an issue if not well managed. Concerning the vision and resources farm organisations have and how they manage them their attitude to business risk determine how expansion is achieved. Farm tourism organisations are typically saddled with tension around expansion (diversification) and risk taking. This came out clearly in the findings with one of the respondents highlighting 'appetite for risk taking' and being proactive being key in decision to diversify. It was also noted that professional advice play vital role in shaping farm attraction operators' attitude towards business risk as professional advisers can nudge them 'to sort the farm out because it can't carry on as it is'. Bureaucracy that characterises their environment can also be a contributing factor especially regarding planning regulations and access to finance. 


\section{Access to finance}

While operators' motivations for diversification vary depending on individual circumstance and abilities, the issue of funds for business expansion is a common denominator. In the context of this study, access to financial support and funding does not feature prominently even though Morris, Henley \& Dowell, (2017) submit that among others drivers and opportunities for diversification is incentive. Operators rather than depend on public funding seek creative ways of sourcing funds. The results show that operators find accessing public financial incentives laborious and time consuming. However, there are occasional successes in applying for grants as one of the respondents reported: 'We did get a rural regeneration grant from Hereford of all places, $£ 62 k$ I think, but nothing from Shropshire’. Also, another respondent commented in this light by saying 'we did get some money from the rural regeneration fund at the beginning'; however, there seems to be a shortage of bid writing skills among operators. It can also be inferred that that organisation processes are not robust enough to accommodate bid activities. In agreement with Sharply and Vass' (2006) conclusion that grants is not a pressing facilitating factor for diversification; in contrast to accessing public funds operators would prefer to ' $\mathrm{g} o$ on with it and do it by themselves' to avoid delaying new product commissioning and disrupting product innovation.

\section{Innovations}

The idea that tourism organisations located in destinations which significantly reflect the nature of the location are required to generate continuous and radical innovation in order to be competitive (Martinez-Perez, Elche \& Garcia-Villaverde, 2019) and sustainable came out strongly in this study. Three elements of innovation - product, organisational and market innovations emerged in this study.

\section{Product innovation}

The results of this study reveal that farm attraction operators are more product-focused rather than marketing led. This create further support for Hjalager's (2010) observation that product innovation is often the focus of many tourism organisations because this is usually the changes tourists can directly observe and consider as innovative. Incorporating new ideas and activities into a product profile logically is understandable in the context of diversification. In addition, operators in this study were keen to create valued experiences for visitors because they were constantly reinventing themselves not only because of the necessity to keep their businesses afloat, but because of the business environment they found themselves is very 
dynamic and highly competitive. Particularly operators were taking advantage of the fact that direct sales of farm produce are popular choices as the demand for fresh food at 'farm' prices is popular with consumers, coupled with the fact that it requires minimal investment as noted by Meert et al (2005). This is exemplified in the statement: 'the majority of what we sell is produced on the farm, this has led to the development of our cooked ready meals which encouraged different customers to buy from us and visit the shop'. Operators do not only diversify to the sale of farm produce and woodland walk for visitors to see where their produce comes from. They augment their product profile with complementary products. For instance one of the respondents volunteered the following statement: 'we do look for complimentary products to sell in the shop and homemade bakery items are now made here onsite'. Product innovation may also appear easier to achieve by farm tourism operators because additional knowledge or extra resources to develop complementary product may be minimal or non-existent (Meert et al., 2005). Innovations in developing products that can attract visitation are more noticeable in the practices of the case organisations. Products such as pop-up opera, bicycle polo, food festivals, holiday cottages, museum, woodland enterprise and farm tours are examples of new product development engaged in by operators in this research.

\section{Organisation innovation}

The three organisations in this study are quite pragmatic in their orientation and this reflects in their responses in adopting and implementing new management practices, strategic directions and reforms. However, despite spontaneity and agility that underpin their organisational innovation planning and processes are often ad hoc which makes their process innovation relatively indistinctive. Process innovation even though distinctively identified in the literature is not uniquely evidenced among the practices of farm attraction operators; rather it is subsumed in organisational innovation providing support for Toivonen \& Tuominen's (2009) argument that the distinction between the different types of innovation could over-lap in tourism and hospitality contexts. For instance, the statement 'We didn't, we just got on and did it by ourselves to begin with.' sums up investigation relating to orientation of the case organisations in terms of organisational and processes innovations. Again, the statement volunteered by one of the respondents reflects the orientation of all the case organisations: 'We have always been a close family but I think we are much closer now, developing stuff together and it has made us more ambitious as well.' depicts family ties 
determine organisation innovation, which in turn reflects on processes for executing innovations.

\section{Marketing innovation}

Marketing innovation lags behind other activities presented by participants in the study, even though they appreciate the importance of marketing and marketing innovation. One of the respondents confessed 'I have to say we are not doing as much marketing as we should do.' Even though the literature suggests that the most common form of innovation is marketing in the face of technological advancement and proliferation of information and communication technology. Little advantage of technology is harnessed. Marketing effort is often informal and based on family decision as operators in cases have families 'sit down and look at new things we can do, like the pop-up opera and now polo so it's a family decision.' However, operators are often customer focused as Brandth and Haugen (2011) noted that farmers need to be sensitive to consumer expectations in order to create a positive experience for visitors who patronise their businesses. The importance of this is exemplified in the following quote from one of the respondents:

We are much more open to what's going on and what people want and what we can do to help them, so if people want to know where their food come from we can provide that - it has opened our eyes to a lot of things and has certainly provided an income for all the family who are involved.

\section{Innovation practices and managing innovations}

The key themes that emerged in terms of innovation practices in farm attraction sector in the context of this study include:

- Leadership - leadership by action and example came across strongly. Leadership is often provided by the head of the family or person in charge of the business.

- Defined focus - the results show that the case organisations are quite focussed in their practice. Defined focus cut across product, organisational and marketing innovation and can be identified in product development, target market, product choice, business expansion and re-investment/divestment.

- Benchmarking - benchmarking of activities and products with other farm shops and attractions is another practice that farm organisations engage in to innovate. Whilst the results show that this is done and considered important the process of executing this is not clear. 
- Consultation - consultation with and seeking services of experts is another key theme in innovation practices among farm attraction operators.

- Planning - although the planning process is not clearly identified, it is done at informal and ad hoc level; however, it is taken seriously when occasions demand.

Operators in this study engaged in the management of innovation based on the themes listed above. The results revealed that organisations in the sector employed creative way of managing innovation particularly in human resources management and leadership. Managers use their formal training to augment the management of the business even where qualifications and previous experience were not cogent in the field of tourism. For instance one respondent commented 'I was in the civil service for many years and managed to get up to Whitehall, briefing ministers and even the PM so I learnt a lot about people and managing people.' Management of human resources featured prominently because the tourism industry generally is human labour dependent. Issue of shortage of labour is augmented by pool of local students who work on temporary contracts to cater for special events. However, recruitment of specialist workers e.g. chef can be daunting, and this requires quite an innovative management of recruiting and retaining.

Maintaining focus allow for differentiation. The organisations try as much as possible to sustain focus e.g. separating different and conflicting aspects of the business. The results also support Morris, Henley \& Dowell's (2017) findings that farms in their bid to be creative may solicit the service of professionals/consultants. Equally, they engage in research and development although market research in instances is limited to basic survey by sending ' $a$ questionnaire around the village telling people what we intended to do'. Whilst majority of the practices enhance innovation, there are limitations in instances. Whilst families can help shape the focus of the business and give it its identity, family members sometimes find it hard to reach a consensus. This is not uncommon to family run business as McFadden \& Gorman (2016) note that farm households face uncertainty regarding whether to diversify and to what extent this should be. This makes managing innovation somewhat difficult and can cause delay in reaching decision. Also, there is no definite planning process; this is evident from the fact that process innovation which is one of the prominent dimensions of innovation (OECD, 2005 ) is hardly identifiable in this context. In addition, resources can be overstretched. Collaboration is also an aspect to improve particularly in the area of marketing because farms 
even though are competitors should rather be seen as partners because issues confronting organisations are similar and joint efforts can help in solving the issues. Schofield et al. (2018) emphasised the notion of collaborative innovation which transcend engagement with traditional stakeholders.

\section{Competitive advantage}

Based on the findings of this study, the two key subthemes that drive competitive advantage are business potential and competitive environment. In relation to competitive environment, main focus of respondents in this subtheme is on competition in the area of farm produce. Whilst Meert et al (2005) note that direct sales of farm produce are popular choices as the demand for fresh food at 'farm' prices is popular with consumers, key competition comes from low price supermarkets. From the respondents' perspective:

\footnotetext{
The supermarkets are our main competition, like we now have a Spar shop in the village but last night even my sister had a delivery from Tesco here and we have Lidl and Aldi now, the cheaper ones who are now tending to specialise much more.
}

Additionally, while there are numerous competing farm attractions, they seem differentiated in their diversification and product offerings and are quite sensitive to the needs of customers as suggested by Brandth and Haugen (2011). The history of each farm determines to some extent the kind of diversification e.g. diversification into museum due to war history. This is portrayed in the following:

Farm shops do tend to support each other and now we have the shop in Myddle selling Hereford beef. Farm shops do tend to do the same thing and so Battlefield in Shrewsbury have a farm shop and a café but hey were able to use existing buildings and have a museum for the battle of Shrewsbury in 1403 so every farm shop is slightly different and you can tell where each farm shop has come from.

Urbanisation is opening up places and some of the respondents see this as a treat which is understandable because their main focus, farming, can be challenged by supermarkets. However, as leisure facilities this could mean increase footfall albeit their unique sense of place could be adversely affected.

The other driving force for competitive advantage is business potential. Respondents recognise that they '...needed sufficient scale to make this a worthwhile business 
proposition'. It seems all the cases in this study possess substantial potential to be viable as suggested by submissions such as 'The addition of the farm shop has been a huge boost to the farm as it has allowed us to expand the farm to meet the needs of the shop' are testimonials to possibility of substantial capacity. Findings support Haven-Tang and Jones (2005) submission that the ability to create a sense of 'place' and a unique visitor experience for consumers is a key differentiation factor. However ability to sustain growth potential is another factor in question as observed by one respondent who stated that 'The business has been growing at $25 \%$ per year but we can't sustain that rate of growth while we are doing everything ourselves so do need to be realistic going forward'.

\section{Conclusion}

The summary of this research outcome is organised around the key themes identified a priori; results show the themes are mutually related. Unlike Fadden and Gorman (2016) that looked at innovative and non-innovative farm family operations, this study looked at farm attractions adopting resource base approach to examine diversification and engagement with innovations in order to achieve competitive edge in an increasingly volatile business environment. On the basis of the discussion of themes that emerged from the findings, a framework (figure 3 ) that summarises the outcome of the study was developed. Figure 3 indicates that there are other factors that need to be considered in understanding issues relating to diversification, innovations and competitiveness in farm attraction context.

The study concurs with Fadden and Gorman (2016) that different farm organisations have different needs that require different level of innovativeness. Three distinct elements of innovation emerged namely: organisational, product and market innovations. Process innovation as identified by the literature is not distinctive among the practices of farm attraction operations. It is rather subsumed in organisational innovation. Also, product innovation is the most distinct practice. Market innovation is also identifiable even though operators rated themselves lowly but many of their activities are geared towards increasing footfall. Overall, the research suggests that farms are more product innovation led rather than marketing focussed. 
Fig 3. Revised framework

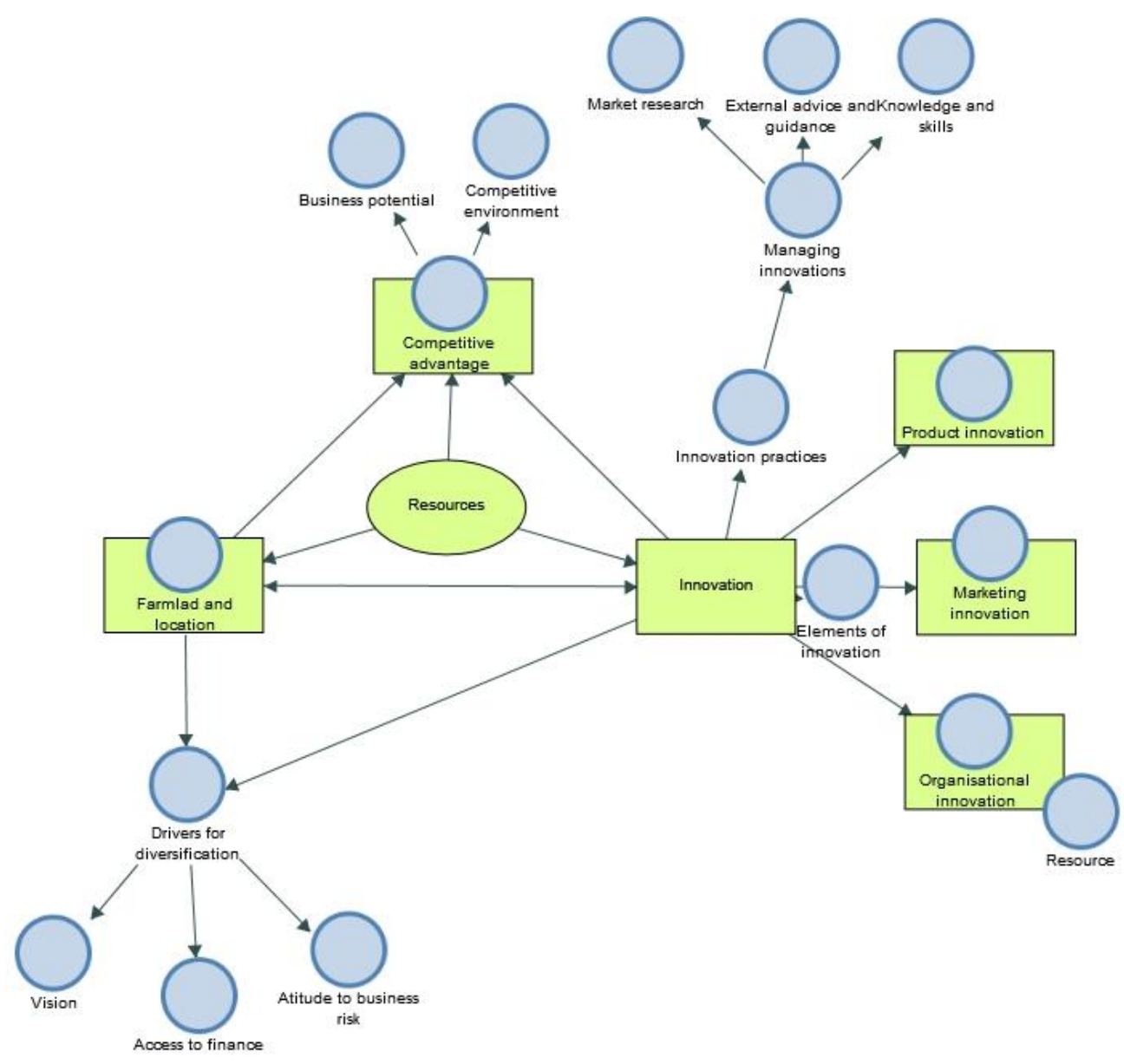

The study also revealed that farmers are dynamic operators who are not only motivated to diversify because of financial constraints but can be inspired by entrepreneurial capabilities and innovativeness and be purposeful in building viable tourism business. Vision and business attitude are often shaped by extant resources particularly land and location. Management and practices of innovation in order to achieve Competitiveness although underlined by tangible resource, farmland, is beset with a number of constraints including limited scope for physical expansion, skills and expertise, family dynamics and 'usual' competitors. Whilst the business environment continues to be competitive it is not farm/farm attractions that operators consider as key competition. Operators consider budget grocery retailers as major competition because their main business is farming and sale of farm produce is deemed their mainstay business expansion. 
Theoretically, this study contributes and supports the existing literature strengthening the argument that typology of innovation can be blurry. In the context of farm attraction, it points out that process innovation is not clearly visible particularly among small, family run farms. The study also contributes to practice as it highlights some practical implications. Farm attraction organisation need to develop their process innovation which is a series of backstage activities that enhance efficiency and productivity (Trunfio \& Campana, 2019). They need to generate new combinations of processes to empower and equip staff to deal with operational issues.

Like most research, this study is without its imitations. It is important to emphasise that this research project has not drawn on a sample representative of farm attraction due to the limited number of cases utilised as a result of the nature of the research - case study, hence results should be adopted with caution. However, the findings are indicative of diversification and innovation practices common to operators in the area of study in achieving competitive edge within changing business environment. Future research should explore the variables examined in the present study from a quantitative perspective as mirrored in Walsh, Lynch and Harrington's (2010) proposal.

\section{References}

Aldebert, B., Dang, R. J., \& Longhi, C. (2011). Innovation in the tourism industry: The case of Tourism@. Tourism management, 32(5), 1204-1213.

Andersen, J. (2010). Resource-based competitiveness: managerial implications of the resource-based view. Strategic Direction, 26(5), 3-5.

Baker, S. E., \& Edwards, R. (2012). How many qualitative interviews is enough? NCRM EPrints Repository accessed 30/07/2019 http://eprints.ncrm.ac.uk/2273/4/how_many_interviews.pdf

Barbieri, C., Xu, S., Gil-Arroyo, C., \& Rich, S. R. (2016). Agritourism, farm visit, or...? A branding assessment for recreation on farms. Journal of travel research, 55(8), 1094-1108.

Barbieri, C., \& Mahoney, E. (2009). Why is diversification an attractive farm adjustment strategy? Insights from Texas farmers and ranchers. Journal of rural studies, 25(1), 58-66.

Barney, J. (1991). Firm resources and sustained competitive advantage. Journal of management, 17(1), 99-120. 
Bazeley, P., \& Jackson, K. (Eds.). (2013). Qualitative data analysis with NVivo. Second edition. London: Sage Publications Limited.

Bowler, I., Clark, G., Crockett, A., Ilbery, B. and Shaw, A. (1996) The development of alternative farm enterprises: A study of family labour farms in the Nothern Pennines of England, Journal of Rural Studies, 12(3), 285-295.

Brandth, B., \& Haugen, M. S. (2007). Gendered work in family farm tourism. Journal of Comparative Family Studies, 379-393.

Brandth, B., \& Haugen, M. S. (2010). Doing farm tourism: The intertwining practices of gender and work. Journal of women in culture and society, 35(2), 425-446.

Brandth, B., \& Haugen, M. S. (2011). Farm diversification into tourism - Implications for identity. Journal of Rural Studies, (27), 35-44.

Buhalis, D., \& Law, R. (2008). Progress in information technology and tourism management: 20 years on and 10 years after the Internet -The state of eTourism research. Tourism management, 29(4), 609-623.

Camison, C., \& Monfort-Mir, V. M. (2012). Measuring innovation in tourism from the Schumpeterian and the dynamic-capabilities perspectives. Tourism management, 33(4), 776789.

Cassel, S. H., \& Pettersson, K. (2015). Performing gender and rurality in Swedish farm tourism. Scandinavian Journal of Hospitality and Tourism, 15(1-2), 138-151.

Clarke, J. (1996). Farm accommodation and the communication mix. Tourism management, 17(8), 611-616.

Clarke, J. (1999). Marketing structures for farm tourism: beyond the individual provider of rural tourism. Journal of Sustainable Tourism, 7(1), 26-47.

Creswell, J. W. (1998). Qualitative inquiry and research design: choosing among five traditions, Thousand Oaks, CA: Sage Publications.

Davies, E. T., \& Gilbert, D. C. (1992). A case study of the development of farm tourism in Wales. Tourism Management, 13(1), 56-63.

Davies, P. (2019). The Leisure Outlook UK June 2019, Mintel Group Ltd., accessed 23/07/2019 http://academic.mintel.com/Sinatra/oxygen/print/id=962342

Engeset, A. B., \& Heggem, R. (2015). Strategies in Norwegian farm tourism: Product development, challenges, and solutions. Scandinavian Journal of Hospitality and Tourism, 15(1-2), 122-137.

Euromonitor (2019). Meat in the United Kingdom, Euromonitor International accessed 23/07/2019 http://www.portal.euromonitor.com.ezproxy.wlv.ac.uk/portal 
Farm Stay (2017). About Farm Stay UK accessed 06/11/2017

http://www.farmstay.co.uk/About

Fleischer, A., \& Felsenstein, D. (2000). Support for rural tourism: Does it make a difference?. Annals of tourism research, 27(4), 1007-1024.

Forbord, M., Schermer, M., \& Grießmair, K. (2012). Stability and variety-Products, organization and institutionalization in farm tourism. Tourism Management, 33(4), 895-909.

Frater, J. M. (1983). Farm tourism in England-Planning, funding, promotion and some lessons from Europe. Tourism management, 4(3), 167-179.

Garcia-Ramon, M. D., Canoves, G., \& Valdovinos, N. (1995). Farm tourism, gender and the environment in Spain. Annals of tourism research, 22(2), 267-282.

Gasson, R. (1988). Farm diversification and rural development. Journal of Agricultural Economics, 39(2), 175-182.

Haugen, M. S., \& Vik, J. (2008). Farmers as entrepreneurs: the case of farm-based tourism. International Journal of Entrepreneurship and Small Business, 6(3), 321-336.

Haven-Tang, C., \& Jones, E. (2005). Using Local Food and Drink to differentiate Tourism Destinations through a sense of Place: A story from Wales - dining at Monmouthshire's Great Table. Journal of Culinary Science and Technology 4(4), 69-86.

Hjalager, A. M. (1996). Tourism and the environment: The innovation connection. Journal of Sustainable Tourism, 4(4), 201-218.

Hjalager, A. M. (2010). A review of innovation research in tourism. Tourism management, 31(1), 1-12.

Hjalager, A. M., Kwiatkowski, G., \& Ostervig Larsen, M. (2018). Innovation gaps in Scandinavian rural tourism. Scandinavian Journal of Hospitality and Tourism, 18(1), 1-17.

Ilbery, B. W. (1991). Farm diversification as an adjustment strategy on the urban fringe of the West Midlands. Journal of Rural studies, 7(3), 207-218.

Ilbery, B.W. \& Bowler, I.R. (1998). From agricultural productivism to post-productivism. In B.W. Ilbery (Ed.) The Geography of Rural change, Harlow: Longman, pp. 57-84

Ingram, G. (2002). Motivations of farm tourism hosts and guests in the South West Tapestry Region, Western Australia: A phenomenological study. Indo-Pacific journal of phenomenology, 2(1), 1-12.

Jalonen, H. (2015). Dancing with the paradox: social media in innovation through a complexity lens. International Journal of Innovation Management, 19(1), 1-26.

Johannessen, J. (2013), Innovation: a systemic perspective - developing a systemic innovation theory. Kybernetes, 42(8), 1195-1217. 
Kessler, A., Pachucki, C., Stummer, K., Mair, M. \& Binder, P. (2015). Types of organizational innovativeness and success in Austrian hotels. International Journal of Contemporary Hospitality Management, 27(7), 1707-1727.

Kuzmanic, M. (2009). Validity in qualitative research: Interview and the appearance of truth through dialogue. Horizons of Psychology, 18(2), 39-50.

Lange, A., Piorr, A., \& Zasada, I. (2013). Spatial differentiation of farm diversification: how rural attractiveness and vicinity to cities determine farm households' response to the CAP. Land Use Policy, 31, 136-144.

Li, C. H. S., Rahimi, R. \& Stylos, N. (2017). Selling to customers in Oriade, A. \& Robinson, P. (Eds.) Rural tourism and enterprise: Management, marketing and sustainability, Wallingford: CABI

Liu C.Z. (2010) Rural development and rural tourism in Taiwan. Asian Journal of Arts and Sciences, 1(2) 211-227.

Martínez-Pérez, Á., Elche, D., \& García-Villaverde, P. M. (2019). From diversity of interorganizational relationships to radical innovation in tourism destination: The role of knowledge exploration. Journal of destination marketing \& management, 11, 80-88.

Maude, A. J. S., \& Van Rest, D. J. (1985). The social and economic effects of farm tourism in the United Kingdom. Agricultural Administration, 20(2), 85-99.

McFadden, T., \& Gorman, M., (2016). Exploring the concept of farm household innovation capacity in relation to farm diversification in policy context. Journal of Rural Studies, 46, 6070 .

Meert, H., van Huylenbroeck, G., Vernimmen, T., Bourgeois, M., \& van Hecke, V. (2005). Farm household survival strategies and diversification on marginal farms. Journal of Rural Studies (21) 81-97.

Morris, W., Henley, A., \& Dowell, D. (2017). Farm diversification, entrepreneurship and technology adoption: Analysis of upland farmers in Wales. Journal of rural studies, 53, 132143.

National Farm Attractions Network (2013) NFAN and its contribution to Tourism accessed 03/11/2017 http://www.farmattractions.net/about-the-national-farm-attraction-network/farmattraction-tourism-industry/

Nickerson, N. P., Black, R. J., \& McCool, S. F. (2001). Agritourism: Motivations behind farm/ranch business diversification. Journal of Travel research, 40(1), 19-26.

OECD (2005) Oslo manual: Guidelines for Collecting and Interpreting Innovation Data, 3rd Edition, European Commission, OECD Publishing. Accessed $14^{\text {th }}$ March 2018 https://www.oecd.org/sti/inno/oslomanualguidelinesforcollectingandinterpretinginnovationda ta3rdedition.htm 
Ollenburg, C., \& Buckley, R. (2007). Stated economic and social motivations of farm tourism operators. Journal of Travel Research, 45(4), 444-452.

Oppermann, M. (1996). Rural tourism in southern Germany. Annals of tourism research, 23(1), 86-102.

Park, D. B., Doh, K. R., \& Kim, K. H. (2014). Successful managerial behaviour for farmbased tourism: A functional approach. Tourism Management, 45, 201-210.

Pettersson, K., \& Heldt Cassel, S. (2014). Women tourism entrepreneurs: doing gender on farms in Sweden. Gender in Management: An International Journal, 29(8), 487-504.

Phelan, C., \& Sharpley, R. (2012). Exploring entrepreneurial skills and competencies in farm tourism. Local Economy, 27(2), 103-118.

Pizam, A., \& Pokela, J. (1980). The vacation farm: a new form of tourism destination. The vacation farm: a new form of tourism destination., 203-216.

Potocnik-Slavic, I., \& Schmitz, S. (2013). Farm tourism across Europe. European Countryside, 5(4), 265-274.

Ritchie, J. \& Lewis, J. (2003). Qualitative Research Practice: A Guide for Social Science Students and Researchers, London: Sage

Schofield, P., Crowther, P., Jago, L., Heeley, J. \& Taylor, S. (2018) "Collaborative innovation: catalyst for a destination's event success. International Journal of Contemporary Hospitality Management, 30(6), 2499-2516

Sharpley, R., \& Vass, A. (2006). Tourism, farming and diversification: An attitudinal study. Tourism management, 27(5), 1040-1052.

Shropshire Star (2015) £500,000 to aid rural tourism growth in Shropshire, July 302015 accessed 30/07/2019 https://www.shropshirestar.com/news/2015/07/30/500000-to-aid-ruraltourism-growth-in-shropshire/

Sirmon, D. G., Hitt, M. A., Ireland, R. D., \& Gilbert, B. A. (2011). Resource orchestration to create competitive advantage: Breadth, depth, and life cycle effects. Journal of management, 37(5), 1390-1412.

Suess-Reyes, J., \& Fuetsch, E. (2016). The future of family farming: A literature review on innovative, sustainable and succession-oriented strategies. Journal of rural studies, 47, 117140.

Toivonen, M., \& Tuominen, T. (2009). Emergence of innovations in services. The Service Industries Journal, 29(7), 887-902.

Trunfio, M. \& Campana, S. (2019). Drivers and emerging innovations in knowledge-based destinations: Towards a research agenda. Journal of Destination Marketing and Management, 14, https://doi.org/10.1016/i.jdmm.2019.100370 
Walsh, M., Lynch, P. \& Harrington, D. (2010). A Capability Based Framework for Tourism Innovativeness. In: 13th Annual Irish Academy of Management Conference, 1st-3rd September, 2010, Cork Institute of Technology.

Yang, F. X., \& Tan, S. X. (2017). Event innovation induced corporate branding. International Journal of Contemporary Hospitality Management, 29(3), 862-882. 